\title{
Reflecting on the Reflections Driving Variations in Heat Transfer Teaching
}

\section{Dr. Sarah A. Roller, University of Alabama, Huntsville}

Sarah A. Roller is an Assistant Professor in Mathematics Education at the University of Alabama in Huntsville. She received her Ph.D. in curriculum, teaching, and educational policy from Michigan State University. Her research interests include teacher preparation and mentoring practices, research-based instructional strategies for teaching mathematics and STEM education, and teacher development.

\section{Dr. Francis Christopher Wessling, University of Alabama, Huntsville}

Professor, Mechanical and Aerospace Engineering, The University of Alabama in Huntsville, 1985 present Former Chair of the Department (1999 - 2003, 2007) Fellow, ASME Associate Director, Consortium for Materials Development in Space 1985 - 1999 Professor, Mechanical Engineering, University of New Mexico, 1967 - 1979 


\title{
Reflecting on the Reflections Driving Variations in Heat Transfer Teaching
}

\begin{abstract}
Reflecting on teaching is a powerful habit of mind that can improve one's own teaching practice. Reflective practitioners make changes in the moment of teaching (reflection-in-action) and also look back on past teaching experiences (reflection-on-action) to inform planning of future instruction (Schön, 1983). This paper describes an engineering professor's journey through the Reflective Cycle of Course Development, and how his reflections-in-action and reflections-onaction caused him to implement instructional variations within a senior level heat transfer course over three semesters. Looking back, the authors reflect on the reflections driving course variation and discuss considerations for future reflective course development.
\end{abstract}

\section{Introduction}

A powerful habit of mind for improving one's own teaching practice is reflection, and even more specifically reflecting on teaching. Dewey (1933) believed that reflective thinking, particularly around problematic situations, was essential for questioning routines and commonly accepted practices. Schön (1983) identified two types of reflection utilized by reflective practitioners to look back on past teaching experiences and to inform planning of future instruction. Specifically, reflection-in-action, which is thinking that occurs during teaching or in the moment, and reflection-on-action, which is thinking that occurs after teaching.

Teacher induction programs used a Plan-Teach-Reflect-Apply Cycle (Commission on Teacher Credentialing and the California Department of Education, 2011; Educational Testing Service, 2005) that was adapted from Deming (1986) to improve teaching through reflection. The PlanTeach-Reflect-Apply Cycle encourages teacher development by having teachers intentionally plan, teach, reflect upon the teaching episode, and then apply the new knowledge learned from reflection to the next iteration of planning. Scales (2012) represents the process of improving teaching and learning with reflection in and on action as a flowchart that merges the apply step with the plan stage. The flowchart is a repeated plan-teach-reflect sequence, that incorporates reflection-in-action during the teaching stage and reflection-on-action during the reflect stage. Specifically, teachers notice and reflect on moments during a single lesson that stem from monitoring student learning or observing himself or herself; these are reflections-in-action. Following the lesson, the teacher is able to take extended time to ponder about how the lesson went, inquire about particular events, or simply reflect on why things happened the way they did in class. These are reflections-on-action. This collection of thinking about teaching can then be used to intentionally plan the next lesson, and begin the cycle again.

For this paper, the Plan-Teach-Reflect-Apply Cycle that focuses on reflective teaching is extended to consider the larger Reflective Cycle of Course Development (Figure 1), and how reflection guided variations made in iterations of a senior level heat transfer course. Essentially, expanding the grain size of the cycle shifts from a lesson plan to a full course structure. Thus, the Plan stage references the teacher preparing and deciding on the course structure (content, routines, teaching methods, assessment, etc.) that will be used for an entire semester. The Teach 
stage is then the implementation of that course structure throughout the semester. Reflective thinking that occurs during the semester, or while teaching, is classified as reflection-in-action and can lead to course structure changes. The Reflect stage is when the teacher engages in broad reflective thinking about the entire course experience. This stage occurs after the conclusion of the course, and since the teacher is looking back on events that can no longer be changed, this is considered reflection-on-action. New knowledge learned from reflecting-in-action and reflecting-on-action is considered in the Apply stage, where ideas are brainstormed that could possibly enhance the structure of the course for the next iteration.

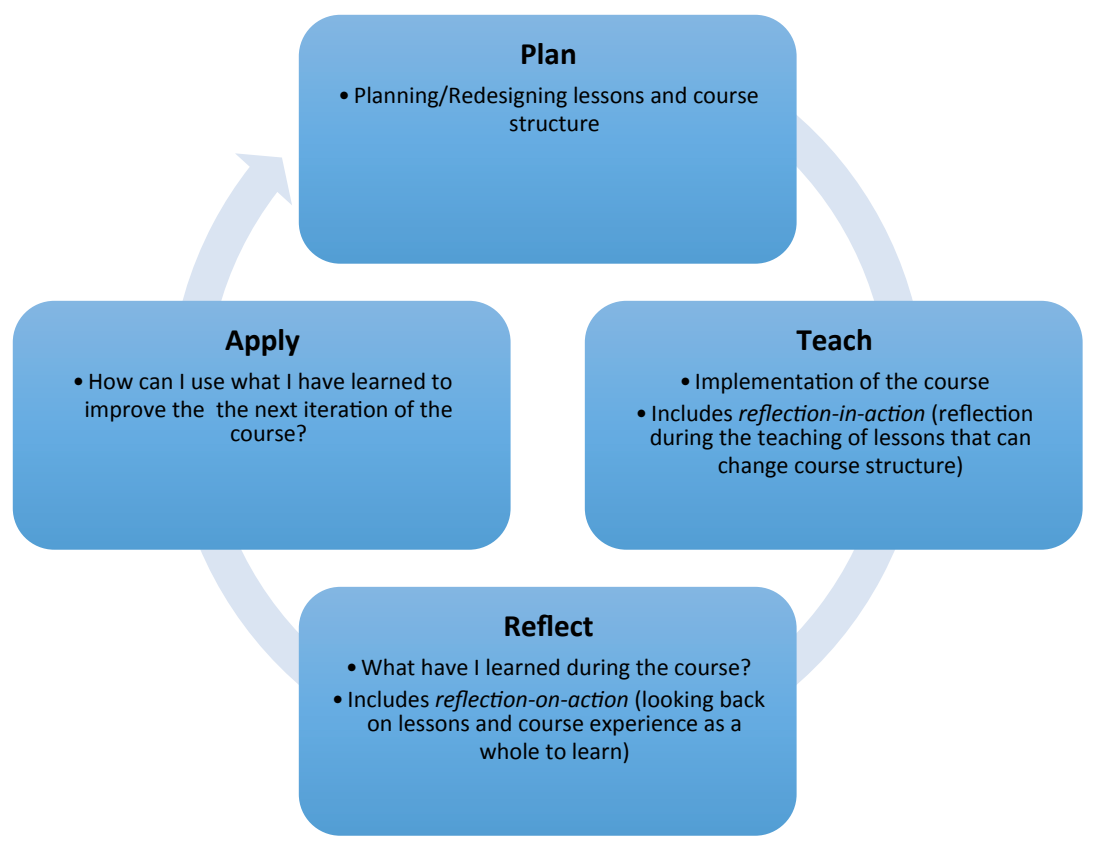

Figure 1. Reflective Cycle of Course Development

This paper describes an engineering professor's journey through the Reflective Cycle of Course Development, and how his reflections-in-action and reflections-on-action caused him to implement instructional variations within a senior level heat transfer course over three semesters. After providing examples, the authors reflect on the reflections driving course variation and discuss considerations for future reflective course development.

\section{The Problem for Reflection}

Dewey (1933) highlighted that reflective thinking stems from commonly accepted routines that seem problematic. In this case, the engineering professor noticed decreases in student achievement and engagement over the past few years and wondered if there were more effective ways of teaching his heat transfer course to increase student learning and engagement. The professor also heard employers wanted students who could communicate and critique ideas and felt it was necessary to be developing these skills along with content knowledge. Based on conversations with colleagues, the engineering professor decided to move away from a 
traditional lecture and tried a flipped classroom approach in his senior level Introduction to Heat Transfer course at our university. It was halfway into this flipped classroom approach course (Semester 1) that the professor reached out to discuss his teaching with a teacher education professor (To read more about his decision to flip the classroom, see Wessling \& Roller, 2016).

\section{Semester 1}

The engineering professor initially structured his heat transfer course using a flipped classroom approach in the following way:

- Prior to attending class, students were required to view pre-recorded lectures (80 minutes) online and expected to apply that knowledge to a set of assigned problems.

- In class, a student would be selected at random to verbally present a solution to a problem.

- While the student articulated the answer, the professor would record the student's explanation on the board so that the other students could follow along.

- The student received participation points based on the quality of the work.

The engineering professor observed students during the class, and began to notice that students were not coming prepared with the problems complete. He also was able to infer that students were not watching the online videos, based on the minimal number of online video views. The students also articulated their frustrations to the professor and other higher administrators about the flipped classroom approach. Based on these informal data, the professor reflected-in-action and decided to have a class discussion one day about the structure of the course. In that conversation, a new structure was agreed upon that would meet the students' needs of wanting more traditional lecture, but also the professor's goal of having students present and critique solutions. This decision to recognize students' high frustration and lack of engagement in course materials and do something different - actually have a conversation with them and make a compromise - was the professor reflecting-in-action and making adjustments accordingly.

Even though a change was made, the professor was still curious about why the students pushed so hard against the flipped classroom structure, and specifically why they were not watching the online videos. Together the engineering and teacher education professors discussed how the flipped classroom structure had placed the lecture and homework outside of the classroom, which was more than just the homework expectation of a traditional lecture class. With this hypothesis in mind, an initial survey was created to gain insights into students' perceptions about the flipped teaching approach, as well as provide information about their time outside of the class.

The survey data (Wessling \& Roller, 2016) revealed more information about who the students were and their time commitments outside of class. For example, most of the students were male, taking a full course load, and employed at least 20 hours a week in a job that would likely lead to an engineering position. The majority of students (81\%) agreed with the statement "I prefer a traditional classroom over a flipped classroom." Along this same sentiment, only $4 \%$ of students agreed, "I will attend a course in which the flipped classroom is used for every class hour." These survey data helped the engineering professor develop a more accurate understanding of his 
students' experiences and their time constraints. He recognized that they were not willing or able to spend the additional time outside of class that his initial flipped classroom approach required, therefore providing a lecture portion to class was a justifiable decision.

Looking back on the course experience and survey data following the end of Semester 1, the professor felt the new compromise structure met students' needs and his course goals regarding content and student communication. Based on these reflections-on-action, the professor decided he would begin with this course structure next semester.

\section{Semester 2}

After a controversial first semester, the professor maintained the compromise adjustments to the course in the following ways:

- Prior to attending class, students had the option to view pre-recorded lectures (80 minutes) online and were expected to complete a set of assigned problems.

- In class, students were selected at random to verbally present a solution to a problem.

- Students presented solutions to assigned problems for 50 minutes and the professor lectured for 30 minutes.

- The professor took a more active part than before in explaining the solution as the student presented the work.

- The student received participation points based on the quality of the work.

This iteration of the course had 15 students, which was much smaller than Semester 1, which contained 65 students. The professor described the course structure as working well. Reflectingon-action, the professor remembered noticing an increase in student-to-student discourse, and hypothesized that this was due to students feeling less intimidated to share within a smaller group of peers. The professor also believed the smaller class size afforded him to stop and answer questions more frequently, enriching the class with discussion that was not there in the first semester. Furthermore, fewer students in the class increased student accountability for homework, because the chances that they would be randomly called upon to present were higher.

Similar to the first semester, the online lecture videos were still largely ignored. Since students were not developing content knowledge from the videos, and because time was a constraint for students previously, the professor hypothesized that these videos were too lengthy. Consequently, the professor planned to shorten the online videos to a more appropriate length, targeting 5-10 minutes.

\section{Semester 3}

The third semester, the professor changed the course structure slightly again, swapping the online lecture videos for mini-videos focused on essential course ideas. The professor also changed the presentation of homework problems to problems done in collaborative groups during class. Thus, the course was structured in the following ways: 
- Prior to attending class, students were given the opportunity to view online mini-videos summarizing concepts (2-14 minutes) and take a quiz over this content to gain participation points. Students were also expected to complete a set of assigned problems.

- In class, the professor presented the material for the next topic for 40 minutes, which included the professor carefully explaining an example problem.

- Students were divided into 14 groups (4-5 students per group) to solve a problem in class.

- One group presented the solution and four groups turned in the results for a grade.

The engineering professor produced mini-videos (2-14 minutes) to replace the longer online lecture videos. The mini-videos allowed the students to get a quick overview of the topics of each chapter so they would be familiar with the concepts and terminology before coming to class to hear the lectures. Typically, less than $10 \%$ of the students viewed the mini-videos (Table 1), however the quiz data (Table 2) display that out of a class of 69 students, the majority of the students completed the quizzes each week and earned $90 \%$ or higher. Since students were given three chances to take the brief quiz, the professor hypothesized that students had realized they could pass the quizzes by seeing when they were wrong on the first quiz and then retaking the quiz for full points again. Students may have also scored well without watching the videos if they read the book. Reflecting on these outcomes (reflection-in-action), the professor made the decision mid-semester to reduce the number of opportunities to complete the quiz to one.

Table 1

Ranked Viewing of Video Sessions by Views, Minutes, and Unique Users

\begin{tabular}{|l|c|c|c|c|c|c|c|}
\hline \multicolumn{1}{|c|}{ Video Session } & $\begin{array}{c}\text { Length } \\
\text { of } \\
\text { Video } \\
\text { (min.) }\end{array}$ & $\begin{array}{c}\text { Unique } \\
\text { Users }\end{array}$ & $\begin{array}{c}\text { Total } \\
\text { Views }\end{array}$ & $\begin{array}{c}\text { Total } \\
\text { Minutes } \\
\text { Viewed }\end{array}$ & $\begin{array}{c}\text { Average } \\
\text { Minutes } \\
\text { Viewed } \\
\text { per User }\end{array}$ & $\begin{array}{c}\text { Percentage } \\
\text { of Students }\end{array}$ & $\begin{array}{c}\text { Average } \\
\text { Percentage } \\
\text { of Video } \\
\text { Viewed }\end{array}$ \\
\hline $\begin{array}{l}\text { Thermophysical } \\
\text { Properties Tables }\end{array}$ & $2: 31$ & 4 & 5 & 9 & 2 & $6 \%$ & $79 \%$ \\
\hline $\begin{array}{l}\text { Diffusion and } \\
\text { Energy Equations }\end{array}$ & $4: 09$ & 4 & 8 & 11 & 2 & $6 \%$ & $48 \%$ \\
\hline $\begin{array}{l}\text { Flow over } \\
\text { Cylinders, } \\
\text { Spheres, and Tube } \\
\text { Banks }\end{array}$ & $10: 47$ & 2 & 3 & 11 & 4 & $3 \%$ & $37 \%$ \\
\hline $\begin{array}{l}\text { Study State and } \\
\text { Transient Finite } \\
\text { Difference }\end{array}$ & $9: 53$ & 3 & 5 & 12 & 3 & $4 \%$ & $30 \%$ \\
\hline $\begin{array}{l}\text { Lumped Mass } \\
\text { Variables }\end{array}$ & $4: 34$ & 4 & 6 & 13 & 3 & $6 \%$ & $66 \%$ \\
\hline $\begin{array}{l}\text { Heat Transfer in } \\
\text { Tubes Part 2 }\end{array}$ & $6: 33$ & 2 & 5 & 14 & 3 & $3 \%$ & $46 \%$ \\
\hline $\begin{array}{l}\text { Extended Surfaces } \\
\text { and Fins }\end{array}$ & $8: 35$ & 5 & 8 & 16 & 2 & $7 \%$ & $23 \%$ \\
\hline
\end{tabular}




\begin{tabular}{|c|c|c|c|c|c|c|c|}
\hline $\begin{array}{l}\text { External Flow over } \\
\text { a Flat Plate }\end{array}$ & $9: 55$ & 3 & 6 & 16 & 3 & $4 \%$ & $30 \%$ \\
\hline $\begin{array}{l}\text { Free Convection, } \\
\text { Part } 2\end{array}$ & $9: 42$ & 2 & 4 & 16 & 4 & $3 \%$ & $41 \%$ \\
\hline $\begin{array}{l}\text { Diffusion and } \\
\text { Boundary } \\
\text { Equations }\end{array}$ & $4: 13$ & 6 & 9 & 17 & 2 & $9 \%$ & $47 \%$ \\
\hline $\begin{array}{l}\text { Internal Flow } \\
\text { Hydrodynamic and } \\
\text { Thermal } \\
\text { Considerations }\end{array}$ & $8: 16$ & 2 & 5 & 18 & 4 & $3 \%$ & $48 \%$ \\
\hline $\begin{array}{l}\text { One Dimension } \\
\text { Stead State No } \\
\text { Internal Heat } \\
\text { Generation }\end{array}$ & 4:06 & 5 & 9 & 22 & 3 & $7 \%$ & $73 \%$ \\
\hline $\begin{array}{l}\text { Forced Convection } \\
\text { Part } 1\end{array}$ & $6: 35$ & 4 & 7 & 23 & 4 & $6 \%$ & $61 \%$ \\
\hline $\begin{array}{l}\text { Free Convection } \\
\text { Part } 1\end{array}$ & $7: 15$ & 3 & 7 & 23 & 4 & $4 \%$ & $55 \%$ \\
\hline $\begin{array}{l}\text { Forced Convection } \\
\text { Part Two }\end{array}$ & $7: 48$ & 4 & 4 & 23 & 6 & $6 \%$ & $77 \%$ \\
\hline $\begin{array}{l}\text { Transient One } \\
\text { Dimensional Heat } \\
\text { Transfer }\end{array}$ & $7: 26$ & 4 & 6 & 25 & 5 & $6 \%$ & $67 \%$ \\
\hline $\begin{array}{l}\text { Heat Transfer in } \\
\text { Tubes, Part } 1\end{array}$ & $11: 26$ & 3 & 5 & 27 & 6 & $4 \%$ & $52 \%$ \\
\hline $\begin{array}{l}\text { Steady State Two } \\
\text { Dimensional } \\
\text { Methods }\end{array}$ & $8: 11$ & 3 & 5 & 37 & 8 & $4 \%$ & $98 \%$ \\
\hline $\begin{array}{l}\text { Heat Exchangers } \\
\text { Part } 2 \text { NTU } \\
\text { Method }\end{array}$ & $9: 34$ & 5 & 7 & 40 & 6 & $7 \%$ & $63 \%$ \\
\hline Boiling & $8: 29$ & 6 & 7 & 54 & 8 & $9 \%$ & $94 \%$ \\
\hline $\begin{array}{l}\text { Heat Exchangers } \\
\text { Part } 1\end{array}$ & $12: 32$ & 6 & 8 & 56 & 7 & $9 \%$ & $56 \%$ \\
\hline $\begin{array}{l}\text { Radiation Part 1a } \\
\text { Fundamentals }\end{array}$ & 8:06 & 8 & 13 & 61 & 5 & $12 \%$ & $62 \%$ \\
\hline $\begin{array}{l}\text { Radiation Part 1b } \\
\text { Black and Real } \\
\text { Bodies }\end{array}$ & 10:01 & 12 & 14 & 90 & 7 & $17 \%$ & $70 \%$ \\
\hline $\begin{array}{l}\text { Radiation } \\
\text { Exchange Between } \\
\text { Surfaces }\end{array}$ & $8: 33$ & 31 & 43 & 227 & 6 & $45 \%$ & $70 \%$ \\
\hline $\begin{array}{l}\text { Radiation of Real } \\
\text { Objects }\end{array}$ & $14: 04$ & 27 & 43 & 321 & 8 & $39 \%$ & $57 \%$ \\
\hline
\end{tabular}




\begin{tabular}{|l|c|c|c|c|c|c|c|}
\hline $\begin{array}{l}\text { Real Surface } \\
\text { Radiation } \\
\text { Exchange }\end{array}$ & $12: 16$ & 34 & 52 & 403 & 8 & $49 \%$ & $65 \%$ \\
\hline
\end{tabular}

Table 2

Number of Respondents and Average Quiz Scores for Each Online Quiz

\begin{tabular}{|l|c|c|}
\hline \multicolumn{1}{|c|}{ Quiz Name/Topic } & $\begin{array}{c}\text { Quiz } \\
\text { Respondents }\end{array}$ & $\begin{array}{c}\text { Average } \\
\text { Quiz Score }\end{array}$ \\
\hline 1) Units in Energy Equation & 68 & 100 \\
\hline 2) Thermophysical Properties & 65 & 99 \\
\hline 3) Boundary Conditions & 67 & 99 \\
\hline 4) Thorium Fuel Rod & 68 & 99 \\
\hline 5) Constant Area Fins & 65 & 97 \\
\hline 6) Conduction Shape Factor & 66 & 95 \\
\hline 7) Lumped Mass & 65 & 92 \\
\hline 8) Transient One Dimensional Heat Transfer & 66 & 97 \\
\hline 9) Transient Finite Difference & 65 & 98 \\
\hline 10) Forced Convection Part 1 & 66 & 96 \\
\hline 11) Forced Convection Part 2 & 67 & 99 \\
\hline 12) Flat Plate Heat Transfer & 64 & 98 \\
\hline 13) Flow over Cylinders, Spheres, and Tube Banks & 65 & 95 \\
\hline 14) Thermal Fundamentals & 67 & 98 \\
\hline 15) Laminar Flow in a Tube & $\mathbf{6 6}$ & $\mathbf{8 7}$ \\
\hline 16) Flow Inside a Tube & $\mathbf{6 7}$ & $\mathbf{6 5}$ \\
\hline 17) Flat Plate Free Convection & 69 & 94 \\
\hline 18) Free Convection Part 2 & 64 & 99 \\
\hline 19) Boiling & 67 & 92 \\
\hline 20) Heat Exchangers, Part 1 & 66 & 92 \\
\hline 21) Heat Exchangers, Part 2 & 66 & 98 \\
\hline 22) Radiation Part 1a Fundamentals & 62 & 96 \\
\hline 23) Radiation with Objects & 67 & 90 \\
\hline 24) Shape Factors & 63 & 94 \\
\hline 25) Real Surface Radiation Exchange & $\mathbf{6 7}$ & $\mathbf{8 1}$ \\
\hline
\end{tabular}

Upon completion of the course, the engineering and teacher education professors reviewed the quiz data and noticed that there were three instances where the average quiz score was lower than $90 \%$. Upon reflecting on these three quizzes, the engineering professor identified that these three quizzes required students to do calculations that were more complicated than typical quiz content. This shift in difficulty may have caught students off guard or less prepared. Students were also able to take quizzes three times initially, and only once later in the semester, which is also when the lower quiz scores appeared. 
The other change the engineering professor implemented during this iteration was having students complete a problem in a group during class. While teaching, the professor noticed that some students chose to work by themselves first, and then communicated with group members when they were satisfied with their individual solution, instead of working the problem together. Reflecting on this change after the course, the professor believed that using group problems resulted in more students-to-student interactions (even if not those anticipated) and students being more interactive with the professor when the professor was presenting material. This broader reflection was a reflection-on-action.

\section{Reflecting on the Reflections Driving Course Variation}

The variations in the Heat Transfer Course described above stemmed from reflecting on teaching and learning. The first semester demonstrates how collecting data allowed the professor to get to know his students and the time constraints they were under while enrolled in his course. He was able to begin making modifications in the course, such as adding a lecture component in response to the students' concerns and needs, and later providing shorter online mini-videos after the second semester of students also minimally viewed the online lectures. Semester 3 revealed the professor intentionally reflecting on achievement data (quiz scores) to think about the course structure, and pinpointing particular calculations that students had struggled more to complete.

Across these semesters, there were two emerging themes that recur and drive the decisions of the professor. The first theme or motive for making changes was the professor's goal to develop communication and critique skills among his students. He knew this was a skill that employers were seeking, and thus made this a priority when revising the course. Decisions supporting communication included maintaining the presentation of solutions aspect in class versus a teacher-centered lecture and also having students solve problems in groups. While not every student in the final iteration (Semester 3) presented a solution, the collaborative nature of working in a group encouraged everyone to communicate about the problem. This interaction among group members was important, particularly for the larger class (Semester 3) where students had expressed to the professor their reluctance to ask or say anything in class, as compared to students in the smaller class (Semester 2) who seemed to freely have interchanges with the professor.

The second theme was the balance of student accountability for learning with grading workload. This was less present in the course descriptions, but appeared within reflective conversations between the engineering and teacher education professors. The professor's rationale for randomly selecting students to present and providing participation points for responses was to encourage students to complete the homework problems and be practicing the course content. During Semester 3, the professor attempted to balance the workload again, by collecting only 4-5 groups' solutions to grade each class period. The online quizzes following the videos was another way to help manage grading while encouraging accountability in learning, since these were graded electronically. Overall, it seemed much time was spent and iterative decisions were made searching for a collection threshold, or balance between collecting just enough work for students to be held accountable without overburdening himself, as a large-lecture professor. Overall, it was not surprising to discover these two themes driving the course variations, since 
the professor's initial motivation for flipping the course was to increase student achievement (accountability) and communication skills.

\section{Considerations for Future Reflective Course Development}

The Reflective Cycle of Course Development built from the Plan-Teach-Reflect-Apply Cycle allows for various lenses to be used to guide the reflection-in-action and reflection-on-action in the Teach and Reflect Stages. In the three semesters of senior level heat transfer course iterations, the professor tended to wear lenses around student engagement in course materials and homework completion (accountability) and students' communication and critique skills. While these were helpful lenses for reflection, there may be more productive ones, namely student learning.

The lens, or focus, on student learning during reflection is apparent in the edTPA (The American Association of Colleges for Teacher Education, n.d.), a teacher performance assessment consisting of three interconnected tasks. Similar to the Plan-Teach-Reflect-Apply Cycle, edTPA contains stages, or tasks, in a teaching cycle that support Planning, Instruction, and Assessment. The Assessment component narrows the lens for reflection on student learning to make planning decisions versus lenses of classroom management or the teacher.

In this paper, there is a hint of reflection on student achievement within the Semester 3 iteration of the senior level heat transfer course when the professors pondered why students demonstrated lower achievement on three quizzes. There was also a missed opportunity here, though, to investigate these scores in the moment and dig deeper into current student thinking. Student (mis)conceptions could have then guided intentional planning for instruction or reteaching of a concept, such as the calculations missed in the quizzes. Using formative assessment to inform instruction and providing students with detailed feedback are both effective practices for increasing student achievement (Black \& Wiliam, 2010). Thus, the use of student achievement scores to make adjustments in the curriculum, versus just the course structure, has potential to be more productive for student learning. Along this same line, it may be helpful to connect specific problems to the targeted learning outcomes for the course and collect homework from all students on these selected problems versus a continuous random selection.

\section{Conclusion}

With each cycle of reflection, reflections in and on teaching led to the collection of various pieces of data in an effort to inform decision-making, evaluate changes, and plan future classes. In this paper, survey data was collected to provide insights about students' perceptions regarding the flipped-teaching method, as well as provide information about who the students were and their time commitments outside of class. Student interactions and monitoring during lessons provided informal data about how students were engaging with the course materials (i.e. Number of online video views, observations during collaborative group work). Students' quiz scores were also considered. Overall, this paper provides an authentic example of what cycles of reflection for course development can look like in engineering education, and how reflections in and on action in conjunction with formal and informal data can lead toward variations of teaching. 


\section{References}

The American Association of Colleges for Teacher Education. (n.d.). Using edTPA. Retrieved February 3, 2017, from https://secure.aacte.org/apps/rl/res_get.php?fid=796\&ref=edtpa

Black, P., \& Wiliam, D. (2010). Inside the black box: Raising standards through classroom assessment. Phi Delta Kappan, 92(1), 81-90.

Commission on Teacher Credentialing and the California Department of Education. (2011). FACT: Formative Assessment for California Teachers User's Guide. Retrieved February 3, 2017, from http://www.ctc.ca.gov/educator-prep/CA-teacher-induction.html

Deming, W. E. (1986). Out of the crisis, Massachusetts Institute of Technology. Center for advanced engineering study, Cambridge, MA.

Dewey, J. (1933). A restatement of the relation of reflective thinking to the educative process. Boston: Heath.

Educational Testing Service. (2005). Introduction to the PATHWISE Framework Induction Program. Retrieved February 3, 2017, from www.ets.org/s/efolio/pdf/Intro_PW_FW_Induction_Program07.pdf

Scales, P., (2012). Teaching in the lifelong learning sector. McGraw-Hill Education (UK).

Schön, D. A. (1983). The reflective practitioner: How professionals think in action (Vol. 5126). Basic books.

Wessling, F. C. \& Roller, S. A. (2016). Lessons Learned and Adjustments Made while Teaching Heat Transfer with a Flipped Classroom. In American Society for Engineering Education Annual Conference \& Exposition Proceedings. New Orleans, LA. 